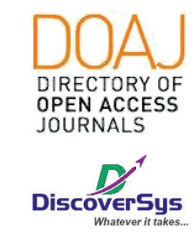

Published by DiscoverSys

\title{
Gambaran pemeriksaan IgM anti-Salmonella thypi 09 pada penderita demam dan gangguan pencernaan, dengan atau tanpa gangguan kesadaran di Puskesmas Denpasar Timur I
}

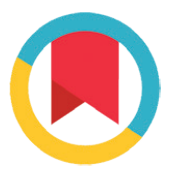

CrossMark

\author{
I Gusti Agung Ayu Ratih Pradnyadewi, ${ }^{1 *}$ Ni Nyoman Mahartini, ${ }^{2}$ I Wayan Putu Sutirtayasa ${ }^{2}$
}

\section{ABSTRACT}

Introduction: Typhoid fever is an endemic disease in Indonesia, which is caused by an infection of the bacterium Salmonella typhi. These bacteria can be transmitted through food and beverages contaminated with these bacteria, can also be caused by contamination of feces and urine from people who have been infected with these bacteria. Enforcement for the diagnosis of typhoid fever can now be done clinically or by laboratory examination. One of them is the serological test that can be used in typhoid fever including the Tubex test.

Method: This research is a descriptive study with a cross-sectional approach. The data in this study came from primary data sources in the form of taking serum of patients in the East Denpasar Health Center I with 33 samples.

Result: Patients who went to the East Denpasar Public Health Center I, found the most group was women $81.9 \%$ while men $18.1 \%$. As many as $100 \%$ came with complaints of fever, $63.7 \%$ came with complaints of nausea and vomiting were $9.0 \%$.

Conclusion: The positive results of anti-Salmonella thypi 09 were $9.1 \%$ and negative IgM anti-Salmonella thypi 09 as much as $90.9 \%$.

Keywords: IgM anti-Salmonella thypi 09

Cite This Article: Pradnyadewi, I.G.A.A.R., Mahartini, N.N., Sutirtayasa, I.W.P. 2019. Gambaran pemeriksaan IgM anti-Salmonella thypi 09 pada penderita demam dan gangguan pencernaan, dengan atau tanpa gangguan kesadaran di Puskesmas Denpasar Timur I. Intisari Sains Medis 10(3): 746-749. D0I: 10.15562/ism.v10i3.422

\section{ABSTRAK}

Latar Belakang: Demam tifoid merupakan penyakit endemik Indonesia, yang disebabkan oleh infeksi dari bakteri Salmonella typhi. Bakteri ini dapat ditularkan melalui makanan dan juga minuman yang terkontaminasi bakteri tersebut, bisa juga akibat dari terkontaminasi dari tinja maupun urin dari orang yang telah terinfeksi. Diagnosis demam tifoid saat ini dapat dilakukan secara klinis maupun dengan cara pemeriksaan laboratorium. Salah satunya ialah uji serologis yang dapat digunakan dalam demam tifoid meliputi tes Tubex.

Metode: Penelitian ini merupakan penelitian deskriptif dengan pendekatan cross-sectional. Data dalam penelitian ini berasal dari sumber data primer berupa pengambilan serum pasien di Puskesmas Denpasar Timur I sejumlah 33 sampel.

Hasil: Pasien yang berobat ke Puskesmas Denpasar Timur I didapatkan kelompok yang paling banyak ialah perempuan 81,9\% sedangkan laki-laki 18,1\%. Sebanyak 100\% datang dengan keluhan demam, sebanyak $63,7 \%$ datang dengan keluhan mual dan muntah $9,0 \%$.

Simpulan: Hasil IgM anti-Salmonella thypi 09 positif sebanyak 9,1\% dan IgM anti-Salmonella thypi 09 negatif sebanyak 90,9\%.
1Program Studi Pendidikan Dokter ${ }^{2}$ Department/SMF Patologi Klinik RSUP Sanglah

Fakultas Kedokteran Universitas Udayana

\section{*Korespondensi:}

IGA Ayu Ratih Pradnyadewi, Program Studi Pendidikan Dokter, igustiagungratih@gmail.com

Diterima: 04-03-2019

Disetujui: 08-11-2019

Diterbitkan: 01-12-2019
Kata kunci: IgM anti-Salmonella thypi 09

Cite Pasal Ini: Pradnyadewi, I.G.A.A.R., Mahartini, N.N., Sutirtayasa, I.W.P. 2019. Gambaran pemeriksaan IgM anti-Salmonella thypi 09 pada penderita demam dan gangguan pencernaan, dengan atau tanpa gangguan kesadaran di Puskesmas Denpasar Timur I. Intisari Sains Medis 10(3): 746-749. D0l: 10.15562/ism.v10i3.422

\section{PENDAHULUAN}

Demam tifoid merupakan penyakit endemik Indonesia, yang disebabkan oleh infeksi bakteri Salmonella typhi. Bakteri ini dapat ditularkan melalui makanan dan minuman yang terkontaminasi bakteri tersebut, bisa juga akibat dari terkontaminasi dari tinja maupun urin dari orang yang telah terinfeksi bakteri tersebut. ${ }^{1,2}$ Bakteri ini akan masuk ke dalam tubuh melalui sistem pencernaan, maka dari itu kebersihan makanan dan juga minuman sangat penting untuk diperhatikan. ${ }^{3}$

Menurut dari data WHO pada tahun 2003, diprediksi sekitar 17 juta kasus demam tifoid di 
seluruh dunia dengan angka insiden 600.000 kasus kematian setiap tahun. Di Indonesia, angka kejadian dari demam tifoid pada tahun 1990 sebanyak $9,2 \%$ per 10.000 penduduk dan pada tahun 1994 mengalami peningkatan menjadi 15,4\% per 10.000 penduduk. ${ }^{4}$

Penggunaan anti bakteria untuk mengobati penyakit yang disebabkan oleh bakteri sangat membantu dunia medis, salah satunya adalah Demam tifoid yang merupakan infeksi bakteri Salmonella typhi Perkembangan bakteri resisten terhadap pengobatan antibakteri akhir2 ini menjadi topik yang didiskusikan di dunia medis. Bayak bukti yang sudah menampilkan kasus untuk bakteri resisten terhadap pengobatan antibakteri di seluruh belahan dunia. Sehingga banyak penelitian dilakukan untuk meneliti pengobatan tradisional yaitu menggunakan ekstrak dari tanaman. Seperti di Indonesia pengobatan tradisional masih menjadi pilihan untuk pengobatan suati penyakit. Namun tidak banyak data yang dapat digunakan sebagai acuan dalam pengobatan tradisional, sehingga penggunaan pengobatan tradsional ditakutkan dapat menjadi permasalah baru dikemudian hari dalam pengobatan penyakit oleh infeksi bakteri. Seperti penelitian yang dilakukan oleh Amertha tahun 2012, ekstrak daun binahong (Anredera cardifolia) tidak memiliki aktivitas dalam menghambat pertumbuhan bakteria seperti Staphylococcus aureus, Enterococcus Faecalis, Escherichia coli dan Pseudomonas aeruginosa. ${ }^{5}$

Untuk menghindari salah diagnosis, perlu dilakukan pemeriksaan penunjang yang dapat membantu klinisi untuk mengambil keputusan dalam mendiagnosis demam tifoid. Diagnosis demam tifoid saat ini dapat dilakukan secara klinis maupun dengan cara pemeriksaan laboratorium. Tubex merupakan salah satu dari beberapa sarana yang dapat digunakan sebagai penunjang diagnosis dari demam tifoid, prosedur pemeriksaan ini cukup sederhana, relatif baru dipasarkan, dan juga hasilnya relatif cepat diketahui. ${ }^{5}$ Pemeriksaan ini mendeteksi antibodi IgM anti-Salmonella thypi 09 pada serum pasien. Apabila ditemukan Salmonella typhi serogroup D pada pemeriksaan ini, maka hasilnya dikatakan positif. penelitian yang dilakukan oleh Olsen dkk, Didapatkan bahwa tes TUBEX memiliki sensitifitas dan spesifisitas tinggi (78\% dan $89 \%)^{1,7}$

\section{METODE}

Penelitian ini merupakan penelitian deskriptif observasional dengan desain penelitian cross-sectional untuk mengetahui Gambaran pemeriksaan $\operatorname{IgM}$ anti-Salmonella thypi 09 pada penderita demam dan gangguan pencernaan, dengan atau tanpa gangguan kesadaran di Puskesmas Denpasar Timur I. Penelitian ini dilakukan di Puskesmas Denpasar Timur 1, pada bulan April hingga Desember 2018. Sampel penelitian ini adalah pasien yang menderita demam datang berobat di Puskesmas Denpasar timur 1 pada bulan April hingga Desember 2018 yang memenuhi kriteria inklusi dan ekslusi. Kriteria inklusi sample adalah pasien demam (pengukuran suhu axilla $>37,50^{\circ} \mathrm{C}$ ), dengan gangguan pencernaan, dengan gangguan atau tanpa gangguan kesadaran. Kriteria ekslusi adalah pasien yang telah mendapatkan antibiotik sebelumnya. Jumlah sampel minimum sesuai dengan rumus slovin pada penelitian ini adalah 33 sampel. 33 sampel penelitian diperoleh dengan menggunakan teknik total sampling.

Variabel yang diteliti dalam penelitian ini adalah Jenis kelamin, gejala klinis yang dikeluhkan seperti, demam (pengukuran suhu axilla $>37,50^{\circ} \mathrm{C}$ ), gangguang pencernaan, dan disertai ataupun tidak gangguan kesadaran) dan pemeriksaan IgM anti-Salmonella thypi 09 dengan uji Tubex. Uji Tubex merupakan salah satu uji serologis yang dapat di lakukan untuk mendiagnosis infeksi bakteri Salmonella thypi. Uji Tubex merupakan uji aglutinasi kompetitif semi kuantitatif kolometrik. Tes ini dapat mendeteksi adanya antibodi anti-Salmonella thypi 09 pada serum pasien. Antigen 09 sangat lah spesifik dan khas pada Salmonella, respon pada antigen 09 sangatlah cepat karena antigen 09 bersifat imunodominan yang dapat merangsang imun.

Penelitian ini menggunakan data primer dengan pemeriksaan IgM anti-Salmonella thypi 09 pada darah dari sample penelitian. Darah dari sampel penelitian diambil pada pembuluh darah vena, dimasukan ke dalam tabung kecil yang steril, kemudian dilakukan sentrifus, dibawa ke laboratorium untuk dilakukan pemeriksaan IgM anti-Salmonella thypi 09. Data yang didapat diolah dan dianalisis menggunakan bantuan program SPSS, kemudian disajikan secara deskriptif dalam bentuk tabel dan diinterpretasikan.

\section{HASIL}

Karakteristik (profil umum) sampel pada penelitian ini adalah perempuan $81,9 \%$, sedangkan laki-laki sebanyak $18,1 \%$. (Tabel 1 ).

Tabel 2. memberikan informasi mengenai hasil pemeriksaan IgM anti-Salmonella thypi 09. Didapatkan hasil positif (+) sebanyak 9,1\%, sedangkan yang negative (-) sebanyak $90,9 \%$. 
Tabel 1 Karakteristik Sampel

\begin{tabular}{lcc}
\hline Variabel & Jumlah (N=33) & Persentase (\%) \\
\hline Jenis Kelamin & & \\
$\quad$ Laki - laki & 6 & 18,1 \\
$\quad$ Perempuan & 27 & 81,9 \\
Demam & & \\
$\quad 37,5^{\circ} \mathrm{C}-38,5^{\circ} \mathrm{C}$ & 27 & 81,9 \\
$39^{\circ} \mathrm{C}-40^{\circ} \mathrm{C}$ & 6 & 18,1 \\
Gangguan Pencernaan & & \\
Mual & 21 & 63,7 \\
Muntah & 3 & 9,0 \\
Diare & 0 & 0 \\
Konstipasi & 0 & 0 \\
Tidak Mual dan Muntah & 9 & 27,3 \\
Gangguan Kesadaran & & 0 \\
Ya & 0 & 100 \\
Tidak & 33 & \\
\hline
\end{tabular}

Tabel 2 Hasil Pemeriksaan IgM anti-Salmonella thypi 09

\begin{tabular}{lcc}
\hline Hasil Pemeriksaan & Jumlah $\mathbf{( N = 3 3 )}$ & Persentase (\%) \\
\hline Positif & 3 & 9,1 \\
Negatif & 30 & 90,9 \\
Jumlah & 33 & 100 \\
\hline
\end{tabular}

\section{PEMBAHASAN}

Penderita dengan gejala demam $>37,5^{\circ} \mathrm{C}$ sebanyak $100 \%$, dengan rincian sebagai berikut: penderita demam $37,5^{\circ} \mathrm{C}-38,5^{\circ} \mathrm{C}$ sebanyak $81,9 \%$, demam $39^{\circ} \mathrm{C}-40^{\circ} \mathrm{C}$ sebanyak $18,1 \%$ dari 33 sampel. Hal ini sejalan dengan penelitian yang dilakukan oleh Rizka (2013) yang melakukan penelitian di RSUD dr. Pirngadi Medan pada April 2012-April 2013 yang menunjukkan gejala demam sebanyak $100 \%{ }^{7}$

Penderita dengan gangguan pencernaan yaitu mual $63,7 \%$ sedangkan muntah sebanyak 9,0\% dan yang tidak mengalami gangguan pencernaan sebanyak $27,3 \%$. Hal ini sejalan dengan peneltian yang dilakukan oleh Rizka (2013) yang melakukan penelitian di RSUD dr. Pirngadi Medan pada April 2012-April 2013 yang menunjukkan hasil 84,2\% mengalami gangguan pencernaan. ${ }^{7}$

Penderita dengan gangguan kesadaran sebesar $0 \%$. Ini sejalan dengan penelitian yang di lakukan oleh Setiabudi (2005) yang melakukan penelitian di RS Hasan Sadikin Bandung yang menunjukkan hasil $1,9 \%{ }^{8}$

Penelitian ini mendapatkan sampel dengan hasil IgM anti-Salmonella thypi 09 positif $(+)$ sebanyak 9,1\%, sedangkan IgM anti-Salmonella thypi 09 negatif (-) sebanyak 90,9\%. Ini sejalan dengan penelitian yang dilakukan oleh Verry dkk (2014) menunjukkan hasil positif (+) sebanyak 19,1\%, sedangkan yang negatif (-) sebanyak 80,6\%. ${ }^{9}$ Gejala klinik yang diperlihatkan oleh penderita yang diduga demam tifoid tidak selalu hasilnya positif mengalami demam tifoid. Gejala tersebut juga bisa terjadi di penyakit lain.

\section{KETERBATASAN}

Studi ini merupakan studi deskriptif yang dilakukan dengan pendekatan potong lintang dimana pengambilan data hanya dilakukan pada satu waktu tertentu. Desain deskriptif tidak dapat digunakan untuk melihat hubungan pemeriksaan IgM anti-Salmonella thypi 09 pada penderita demam dan gangguan pencernaan, dengan atau tanpa gangguan kesadaran. Keterbatasan waktu, pengambilan sampel dari satu pusat menyebabkan studi ini memiliki jumlah sampel yang kecil. Perlu dilakukan penelitian lebih lanjut dengan desain analitikal dan sumber sampel yang lebih dari satu pusat, untuk mendapatkan hasil yang lebih representatif terhadap populasi yang sebenarnya.

\section{SIMPULAN}

Berdasarkan hasil studi ini, maka dapat disimpulkan bahwa kelompok yang paling banyak ialah perempuan $81,9 \%$ sedangkan laki-laki $18,1 \%$. Sebanyak $100 \%$ datang dengan keluhan demam, sebanyak 63,7\% datang dengan keluhan mual 63,7\% dan muntah 9,0\%. Hasil IgM anti-Salmonella thypi 09 positif sebanyak 9,1\% dan IgM anti-Salmonella thypi 09 negatif sebanyak 90,9\%.

\section{KONFLIK KEPENTINGAN}

Penulis menyatakan tidak terdapat suatu konflik kepentingan terhadap publikasi dari artikel ini.

\section{PENDANAAN}

Penelitian ini tidak mendapatkan suatu pendanaan yang diberikan oleh pemerintah ataupun lembaga swasta lainnya.

\section{KONTRIBUSI PENULIS}

Konsep penelitian: I Gusti Agung Ayu Ratih Pradnyadewi, Ni Nyoman Mahartini, I Wayan Putu Sutirtayasa. Pengumpulan data dan input data: I Gusti Agung Ayu Ratih Pradnyadewi. Penyusunan naskah Penelitian: I Gusti Agung Ayu Ratih Pradnyadewi.

\section{ETHICAL CLEARANCE NUMBER:}

1197/UN14.2.2/PD/KEP/2018. 


\section{DAFTAR PUSTAKA}

1. Pratama KY., \& Lestari W. Efektifitas tubex sebagai metode diagnosis cepat demam tifoid. Intisari Sains Medis. 2015. 2(1): 70-73. DOI:10.15562/ism.v2i1.87.

2. Prayoga DK., Fatmawati ND. Identifikasi Salmonella spp pada feses penjamah makanan di rumah potong ayam RJ dengan metode kultur. Intisari Sains Medis. 2018. 9(3). DOI:10.15562/ism.v9i3.287

3. Inawati. Tatalaksana Terkini Demam Tifoid, Departemen Patologi Anatomi, Fakultas Kedokteran Universitas Wijaya Kusuma Surabaya. 2009.

4. Septiawan IK., Herawati S., \& Yasa IWPS. Examination of the immunoglobulin $\mathrm{m}$ anti salmonella in diagnosis of thypoid fever. e-Jurnal Medika Udayana. 2013. 2(6), 1080-1090.

5. Amertha IBPM, Soeliongan S, Kontul C. In vitro inhibition zone test of binahong (Andrea cordifolia). Towards staphylococcus aureus, enterococcus faecalis, escherichia coli, and pseudomonas aureginosa. Indonesian Journal of Biomedical Science. 2012;6(1):30-34.

6. Olsen SJ., Pruckler J., Bibb W., Thanh NTM., Trinh TM., Minh NT., \& Chau NV. Evaluation of rapid diagnostic tests for typhoid fever. Journal of clinical microbiology. 2004. 42(5), 1885-1889.
7. Rizka AS. Profil Penderita Demam Tifoid pada Orang Dewasa di RSUD DR. Pringadi Medan pada April 2012April 2013, Fakultas Kedokteran, Universitas Sumatera Utara, Medan. 2013.

8. Setiabudi D., \& Mediapermana K., Demam Tifoid pada Anak Usia di bawah 5 Tahun di Bagian Ilmu Kesehatan Anak RS Hasan Sadikin Bandung. Sari Pediatri. 2005. Volume 7, No.1.

9. Kusumaningrat IBV., \& Sutirta YI. Uji Tubex untuk Diagnosis Demam Tifoid di Laboratorium Klinik Nikki Medika Denpasar. E-Jurnal Medika Udayana. 2014. 3(1), 22-37.

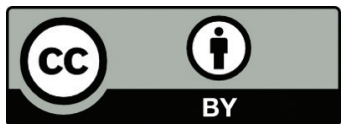

This work is licensed under a Creative Commons Attribution 